\title{
School bus operational performance in Malang City
}

\author{
Septiana Hariyani ${ }^{1,}$, and Dadang Meru Utomo ${ }^{1}$ \\ ${ }^{1}$ Brawijaya University, Department of Urban and Regional Planning, Malang, Indonesia
}

\begin{abstract}
Based on the preliminary observation not all students are interested in using the school bus, despite the school bus's service since 2014 in Malang city. So, this study evaluates school bus operation performance. This study used on board survey to calculate the load factor and travel time of school bus. While static survey is used to collect waiting time for passenger. The results showed that load factor departure and load factor arrival over $70 \%$. Average school bus's travel time departure for six routes was 44-58 minutes, and average travel time arrival for 37-65 minutes for six routes. The last is waiting time for passenger 5-14 minutes.
\end{abstract}

\section{Introduction}

There are five categories of home-based trip destination, namely: 1. To workplace, 2. To school or university (the movement of the purposes of education), 3. To shops, 4. To social interests, and 5. To recreation areas [1]. The movements require a mode of transport to move called transportation, whether it is a private mode or a mode of public transport. One form of public services needed by the community is a transportation service [2]. Transport is an activity of the movement of people and goods from one place (origin) to another (destination) by means of a vehicle. Movement to the school also requires transportation either public transport or private transportation, but there is a special transport that serves students is a school bus.

The results of previous research indicate that the school bus load factor is still low i.e. 0.5 [3]. Speed of school bus trip is reported around $40 \mathrm{~km} / \mathrm{h}$ with travel time of $40-60$ minutes. School bus service time is in the morning and afternoon corresponding to the time to depart and go home from school and has a waiting time of passengers between 5-10 minutes.

Another research indicates that the school bus's level of service in Malang City needs to get more attention to improve the attributes: adequate space, and seating capacity in order to increase its performance [4].

Building upon the previous research, this study aims to evaluate the load factor, travel time of school bus, and waiting time for passenger of Malang's school bus service, since its first operation in 2014.

\footnotetext{
* Corresponding author: septianahariyani@ub.ac.id
} 


\section{Methods}

This study was conducted on six school bus routes in Malang City, namely route A, B, C, D, E, and route F. Route A : Tlogomas - Tugu, route, route B : SPBU Mergan - Tugu, route $\mathrm{C}: \mathrm{T}$. Mardyopuro-Tugu, route D : Sawojajar (Madyopuro Terminal) - Tugu, route E : National electricity company (PLN) Gadang - Tugu, and route F : Samsat Kacuk Tugu. The six school bus routes and school distribution can be seen in Figure 1.

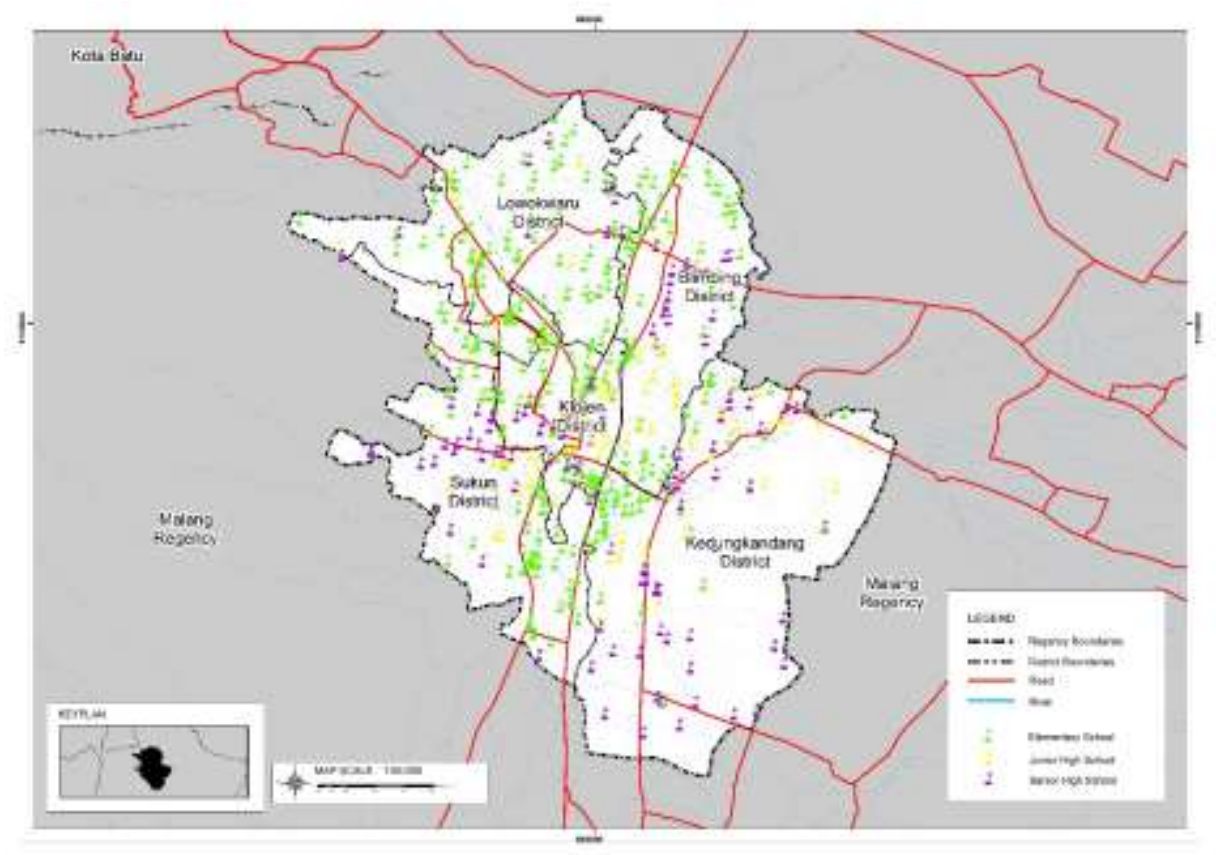

Fig. 1 The six school bus routes and school distribution in Malang City

On board survey was used to calculate the load factor and travel time of the school bus service. While static survey was used to collect waiting time for passenger. Then the data was put into calculation bellow:

\subsection{Load factor}

The standards set by the Directorate General of Land Transport, 1996 (Dirjen Perhubungan Darat) for the load factor value is $70 \%(0.7)$ and there is a $30 \%(0.3 \%)$ reserve to accommodate the possibility of passenger spikes, and at this level the inroads of passengers inside the vehicle are still acceptable [5].

$$
\mathrm{LF}=\frac{\mathrm{Vp}_{\mathrm{p}}}{\mathrm{Cb}} \times 100 \%
$$

Note:

LF : Load factor

$\mathrm{Vp}$ : Average Passenger Volume in the bus

$\mathrm{Cb}$ : bus capacity 


\subsection{Travel time}

Travel time can be defined as the time taken to travel a certain distance and will have a relationship associated with the average speed. Travel time is an indicator that determines the service level of a bus operation. It is clear from the obligations of the bus operator to supply the existing demand, as an indicator of the level of service [6].

If it assumes that the arrival time of the passengers on the bus departure site, the same or different, assuming a constant headway, it can be concluded that the average waiting time for passengers is:

$$
w=\frac{h}{2}=\frac{60}{2 f}
$$

Note :

$\mathrm{W}=$ average passenger waiting time

$\mathrm{h}=$ headway (minutes)

$\mathrm{f}=$ one way bus frequency (bus/hour)

\section{Result}

Geographically Malang is located at coordinates $112^{\circ} 06^{\prime}-112^{\circ} 07^{\prime}$ East Longitude and $7^{\circ}$ 06 '- $8^{\circ} 02^{\prime}$ South Latitude. The city of Malang is located in East Java Province with a population of 900,468 inhabitants [7]. The total area of Malang is $110.06 \mathrm{~km}^{2}$. Malang is the second largest city in East Java after Surabaya.

The school bus is a transportation facility provided by the Education Office of Malang City, where the school bus consists of 5 school buses from the government, 1 school bus from Corporate Social Responsibility (CSR) and 1 reserve school bus also from CSR. Procurement of this school bus by the government provides funds worth 4 billion rupiah for 5 units of buses with the brand IZUSU with type IZUSU / NQN 71 EC. Ez-1 with each bus worth 800 million rupiah per unit. The procurement of school buses is prioritized for less fortunate students living in the suburbs. The buses can be seen in Figure 2 .

School bus procurement began on December 29, 2014 and commenced operations on January 12, 2015, although there was a polemic with the public transport driver who refused and disagreed with the existence of the school bus, the procurement of the school bus is expected to reduce the use of motor vehicles by students and the number of congestion due to transportation. The procurement of the school bus was distributed to six existing routes in Malang City, where the six school bus units were spread with a capacity of 35 passengers seated with 10 passengers standing for the school bus from the municipal government while the school bus obtained from CSR there were only 25 passengers seated and 20 passengers to stand (Figure 3).

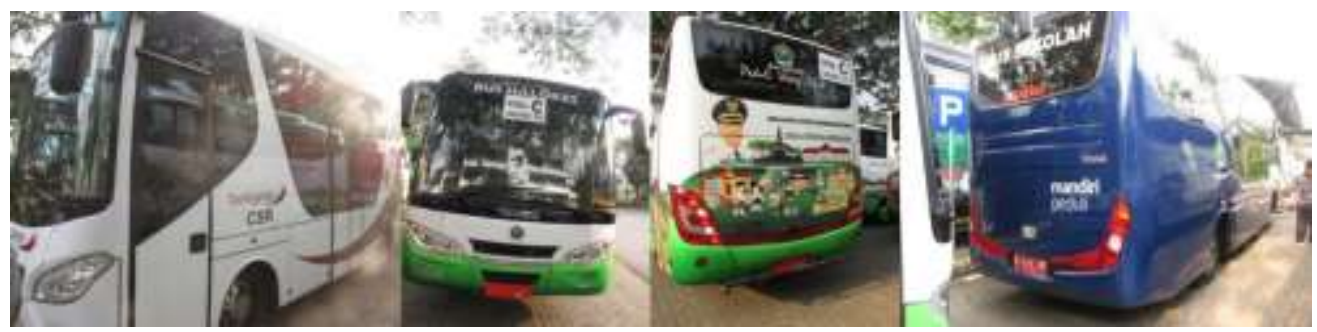

Fig. 2 School bus in Malang City 

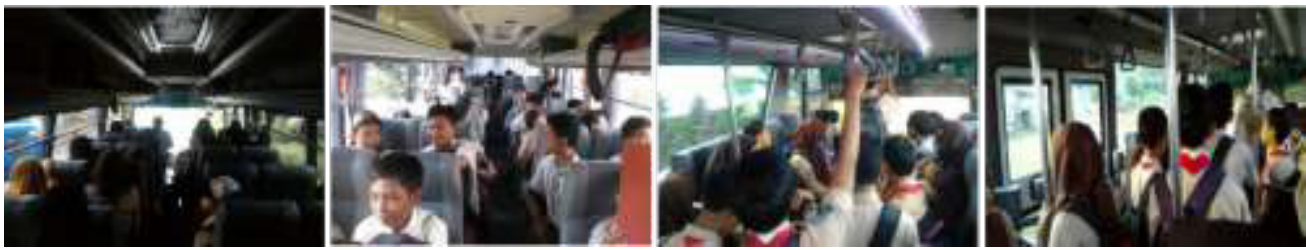

Fig. 3 Inside of school bus

Evaluation of operational performance of school bus in Malang is done by knowing travel time, and load factor. The results of the operational performance evaluation will be used as a basis for improving the operational performance of school buses in Malang.

Load factor is used to measure the capacity of passengers in each journey so as to know the maximum capacity of a mode, besides the load factor serves as a guide to know the availability of the fleet is sufficient, still lacking, or exceeding the needs of a track and an indicator of the efficiency of a route. The seating capacity on the School Bus is 35 seats with 10 stands. The standard for the load factor values established by the Directorate General of Land Transportation is $70 \%$ and there is a $30 \%$ reserve to accommodate in case of a passenger surge. Load factor work is differentiated every school bus that operates. The data used to calculate the load factor is the number of passengers and the capacity of the school bus passengers.

Based on the load factor calculation on each route the excess of passengers has been set by the Directorate General of Land Transport where the standard for load factor value is $70 \%$ and there is $30 \%$ reserve to accommodate passenger spike. This excess of passengers is influenced by some behavioral factors of travelers for poor students in the selection of modes, especially the school bus. Factors that affect, among others, $42 \%$ of students who use school bus have a pocket money ranging from 5000-10000, where the students prefer school buses because it is not necessary to pay to board the school bus so they no longer need to spend additional costs, As many as $88 \%$ of students using school buses travel single trips where they directly choose to go home, as well as a school rule that prohibits students from bringing the vehicle to school by as much as $70 \%$ thus requiring students with private vehicles not to use it to school. Load factor of school bus showed in Table 1.

Travel time can be defined as the time taken to travel a certain distance and will have a relationship associated with the average speed used to travel a certain distance. Factors that affect the travel time of a mode of travel speed, route length, travel time, and waiting time. Based on the result of the travel time calculation on each route, both the travel time and the return time of the average travel time of the school bus takes \pm 50 minutes to reach the end point of the route where as many as $54 \%$ of students who use school buses need travel time ranged Between 10-15 minutes to get to school, 28\% takes 15 minutes and the remaining $18 \%$ takes time to go to school ranging from 5-10 minutes.

Table 1 School bus's load factors (LF)

\begin{tabular}{|c|c|c|}
\hline & LF departure & LF arrival \\
\hline School bus route A & $140 \%$ & $94 \%$ \\
\hline School bus route B & $123 \%$ & $120 \%$ \\
\hline School bus route C & $82 \%$ & $68 \%$ \\
\hline School bus route D & $109 \%$ & $97 \%$ \\
\hline School bus route E & $106 \%$ & $89 \%$ \\
\hline School bus route F & $89 \%$ & $103 \%$ \\
\hline
\end{tabular}


However, after the interview about the school bus time desired by the students is as much as $48 \%$ of students who use school bus wanted travel time $10-15$ minutes, $40 \%$ of students want travel time 5-10 minutes and the rest of $>15$ minutes as much as $12 \%$. The travel time of the school buses on each route is not in accordance with the demand of the students who use it therefore needs consideration to maximize the travel time of the school bus in accordance with the demand desired by the students.

Table 2 School bus's travel time (TT)

\begin{tabular}{|c|c|c|}
\hline & TT inbound (minutes) & TT outbound (minutes) \\
\hline School bus route A & 45 & 65 \\
\hline School bus route B & 57 & 45 \\
\hline School bus route C & 58 & 54 \\
\hline School bus route D & 44 & 39 \\
\hline School bus route E & 45 & 38 \\
\hline School bus route F & 46 & 37 \\
\hline
\end{tabular}

Table 3 Waiting time for passenger

\begin{tabular}{|c|c|}
\hline & Waiting time for passenger (minutes) \\
\hline School bus route A & 12 \\
\hline School bus route B & 10 \\
\hline School bus route C & 11 \\
\hline School bus route D & 5 \\
\hline School bus route $\mathrm{E}$ & 10 \\
\hline School bus route $\mathrm{F}$ & 14 \\
\hline
\end{tabular}

\section{Conclusion}

Since the first commencement in 2015, the utilization of Malang City's school bus service has increased as seen in the relatively high load factor (more than $70 \%$ as set by the Directorate General of Land Transport). With most riders coming from middle income families, despite its rising popularity, there are several points that require improvement to increase the riders' satisfaction. The first point is the necessity of evaluating the route length to provide shorter travel time. Currently, riders expect shorter travel time of 5-10 minutes, while the actual travel time reaches almost an hour. The second is the urgency of providing more fleets to allow shorter waiting time. Based on the findings, this research suggests the local government to consider more effort to provide a better school bus service, not only to improve riders' experience, but also to reduce transportation problem in general.

\section{Reference}

1. Tamin, OZ. Perencanaan dan Pemodelan Transportasi - Edisi Kedua. Bandung: Penerbit ITB. (2000).

2. Warpani, Suwardjoko P. Pengelolaan lalulintas dan angkutan jalan. Bandung: Penerbit ITB (2002).

3. Prasetyo, T, Djakfar, L, and Abusini, S, Evaluasi dan Potensi Pengoperasian Bus Sekolah (Studi Kasus: Bus Halokes Kota Malang), Media Teknik Sipil Volume 13, Nomor 2, p.185-192 (2015). 
4. Hariyani, S. School bus's level of service in Malang City. IOP Conf. Series: Earth and Environmental Science 70 (2017) 012023.

5. Direktorat Jenderal Perhubungan Darat. (1996).

6. Morlok, E. K. Introduction to Transportation Engineering and Planning. Mc. GrawHill Kogakuha. (1978).

7. Office of Demographic Affairs Malang City, Juli (2017) 